\title{
Сонячні абсорбційні системи кондиціювання повітря на основі двоступінчастої регенерації абсорбенту
}

\section{О. В. Дороченко ${ }^{\bowtie, ~ А . ~ Р . ~ А н т о н о в а, ~ О . ~ С . ~ Б о д н я, ~ В . ~ Ф . ~ Х а л а к ~}$}

Одеська національна академія харчових технологій, вул. Канатна, 112, Одеса, 65039, Україна

$\triangle$ e-mail: dor_av43@i.ua

\begin{abstract}
Розроблені принципові схеми багатофункиіональних сонячних систем осушення повітря, теплопостачання (гарячого водопостачання та опалення), холодопостачання та кондиціювання повітря на основі відкритого абсорбиійного ичиклу з прямою (безпосередньою) регенерацією абсорбенту. Такі системи базуються на попередньому осушенні повітряного потоку й наступному випарному охолодженні середовищ у сонячних холодильних системах (СХС) и термовологісної обробки повітря в сонячних системах кондиціювання повітря (ССКП). Авторами використовувався принции двоступінчастої регенерачії абсорбенту. Сонячна система складається з автономних осушно-охолоджувальних блоків, причому кожний ступінь регенерації замкнений на відповідний ступінь абсорбера-осушувача повітря, що дозволяє збільщувати концентрацію абсорбенту від ступеня до ступеня (у діапазоні можливих концентрацій використовуваного розчину бромистого літію LiBr). Розроблені принципові рішення для нового покоління газо-рідинних сонячних колекторів, що забезпечують безпосередню (пряму) регенерачію розчину абсорбенту. Робота тепломасообмінних апаратів, щчо входять в осушувальний і охолоджсвальний контури абсорбиійних систем, базується на принципі плівкової взаємодії потоків газу й рідини з використанням багатоканальної структури із полімерних матеріалів для створення насадки. Попередній аналіз можливостей багатофункиіональних сонячних абсорбиійних систем виконувався на основі експериментальних даних авторів та моделювання процесів тепломасообміну в основних елементах систем, відносно завдань кондиціювання повітря (ССКП). Показано, щңо практично для будь-яких, «важских» параметрів зовнішнього повітря вирішення завдань забезпечення його комфортних параметрів може бути виконано без використання традиційної парокомпресорної техніки. Розроблені сонячні системи ССКП відрізняються малим споживанням енергії й екологічною чистотою.
\end{abstract}

Ключові слова: абсорбиійна система, сонячна енергія, сонячний колектор, регенерація абсорбенту, випарне охолодження, термовологісна обробка, полімерні матеріали.

\section{doi: https://doi.org/10.15673/ret.v55i2.1358}

(C) The Author(s) 2019. This article is an open access publication

This work is licensed under the Creative Commons Attribution 4.0 International License (CC BY)

http://creativecommons.org/licenses/by/4.0/

\section{Скорочення}

TMA

(HMT)

СCPГ

(SARS)

CXC

(SRS)

CСКП

(SACS)

ССГВ

(SHWS) тепломасообмінний апарат (heat and mass transfer apparatus) сонячна система регенерації абсорбенту (solar absorbent regeneration system) сонячна холодильна система (solar refrigeration systems) сонячна система кондиціювання повітря (solar air conditioning systems) сонячна система гарячого водопостачання (solar hot water system)
СКг-p

(SCg-lq)

АБР

(ABR)

ДБР

(DBR)

ГРД

(CTW)

$\mathrm{T} / \mathrm{O}$

$\mathrm{M}, \mathrm{N}$

ж (lq)

$\mathrm{t}, \mathrm{t}_{\mathrm{m}}, \mathrm{t}_{\mathrm{p}}$,

град., C

h, кДж/кг
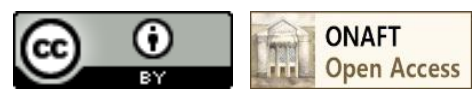

\section{(1)}




$\begin{array}{ll}\text { Х, г/кг } & \text { вологовміст повітря } \\ \text { ЗП } & \text { зовнішнє повітря } \\ \text { OC } & \text { осушений повітряний потік } \\ \text { В } & \text { повітря, що викидається в } \\ & \text { навколишнє середовище }\end{array}$

\section{Вступ}

Сонячні системи кондиціювання повітря (ССКП) базуються на відкритому тепловикористовуючому абсорбційному циклі, у якому попередньо осушення повітря забезпечує високу ефективність наступного випарного охолодження й термовологісної обробки повітря [1-6, 8, 12]. Розроблені рішення охоплюють потреби енергетики, холодильної техніки, хімічної й харчової технологій і дозволяють вирішувати завдання охолодження й кондиціювання не застосовуючи традиційну парокомпресорну техніку, що суттєво поліпшує їх экоенергетичні показники [1, 6-7]. ССКП розробляються як 3 непрямою [1-6], так і з прямою (безпосередньою) регенерацією абсорбенту $[1,2,9-11]$. Пряма регенерація забезпечує можливість конструювання сонячних систем на основі плоских сонячних колекторів-регенераторів і усуває необхідність у десорбері-регенераторі традиційного типу [1].

\section{1. Розробка принципових схемних рішень сонячних систем ССКП на основі двоступі- нчастої регенерації абсорбенту}

Принципова схема розробленої двоступінчастої ССКП представлена на рис. 1. (позначення до рис: 1,3 - абсорбер-осушувач зовнішнього повітря АБР першого й другого ступеня; 2, 4 - випарний повітроохолоджувач непрямого типу НВО [1]; 5, 6 - сонячний газо-рідинний колектор СКг-р (десорбер-регенератор) першого й другого ступеня; 7 градирня технологічного призначення ГРДт, що обслуговує абсорбери; 8 - бак-акумулятор концентрованого розчину абсорбенту; 9, 10, 11 - теплообмінники; 12 - додаткове джерело тепла традиційного типу; ЗП (П) - зовнішне повітря; ОВ - осушене повітря; О - «основний» повітряний потік; В - «допоміжний» повітряний потік для НВО; ВВ повітря, що викидається в навколишнє середовище, для СКг-р; N, M - міцний і слабкий розчини абсорбенту); виділеними точками зазначені параметри повітряних і рідинних потоків.

Сонячні абсорбційні системи із прямою (безпосередньою) регенерацією розчину абсорбенту, забезпечують зниження габаритів, маси й вартості систем, але є чутливими до коливань рівня сонячної інсоляції, тому що в них трансформація сонячної енергії забезпечує одночасно й необхідний температурний рівень регенерації абсорбенту в про- цесі дифузії водяних парів у регенераційний повітряний потік, так і сам рух повітря над поверхнею абсорбенту (авторами використовуються розчини на основі бромистого літію $\operatorname{LiBr}[1-7,8-12])$. Раніше в ОНАПТ [1] розглядалася конструкція одноступеневих сонячних систем ССКП на основі формули [(ДБР↔АБР $)-$ НВОг], де попереднє осушення зовнішнього повітря в абсорбері забезпечувало подальшу інтенсивну термовологісну обробку повітряних потоків «О» у каналах НВОг. У даній статті представлений розроблений базовий двоступеневий варіант ССКП (рис. 1), з використанням газо-рідинних СКг-p (SGg-lq) у якості десорбера-регенератора для кожного ступеня регенерації абсорбенту.

Основна концепція створення ССКП базується на наступних положеннях:

1. ССКП виконана у двоступінчатому варіанті й складається 3 автономних осушноохолоджувальних блоків, виконаних за формулою [(ДБР↔АБР)-НВОг] (блоки А1 i А2), причому кожна ступінь регенерації (ДБР, елементи 5 - 8 і 6 - 8, блоки Б1 і Б2 за ступенями регенерації) замкнена на відповідний ступінь абсорбераосушувача повітря (АБР, елементи 1 - 2 і 3 - 4), відповідно;

2. Десорбер-регенератор виконаний двоступеневим на основі ідентичних блоків у складі газорідинних колекторів СКг-p (Scg-lq) і акумулятора міцного розчину абсорбенту (8). Кожний 3 цих блоків представляє автономний ступінь відновлення концентрації абсорбенту: на першому ступені розчин абсорбенту послідовно проходить кожний ступінь регенерації Б1 і Б2, у яку надходить «свіже» зовнішне повітря, а друга ступінь регенерації може мати додатковий нагрівач розчину традиційного типу у випадку росту концентрації абсорбенту у ступенях Б1 і Б2

Схема осушувальної частини може бути побудована так, щоб на кожний ступінь регенерації (ДБР) був замкнений на відповідний ступінь абсорбера (АБР), що дозволяє збільшувати концентрацію абсорбенту від ступеня до ступеня (у діапазоні можливих концентрацій використовуваного розчину бромистого літію $\mathrm{LiBr}$, що обмежене небезпекою кристалізації розчину при високих концентраціях абсорбенту); повітряний потік (зовнішне повітря), при осушенні в абсорбері, знижує вологовміст $x_{2}$ i температуру точки роси $t_{m p}$, що забезпечує значний потенціал подальшого охолодження у випарному охолоджувачі НВОг; загальна формула ССКП: ЗП $\rightarrow$ (ДБР1 $\leftrightarrow$ АБР1) - НВО1г (ДБР2 $\leftrightarrow$ АБР2) - НВО2г;

3. Внутрішня рекуперація тепла забезпечується системою теплообмінників: на лініях гарячого-міцного (М) і холодного-слабкого $(\mathrm{N})$ розчину бромистого літію LiBr установлені т/о 11 і 11*; на 


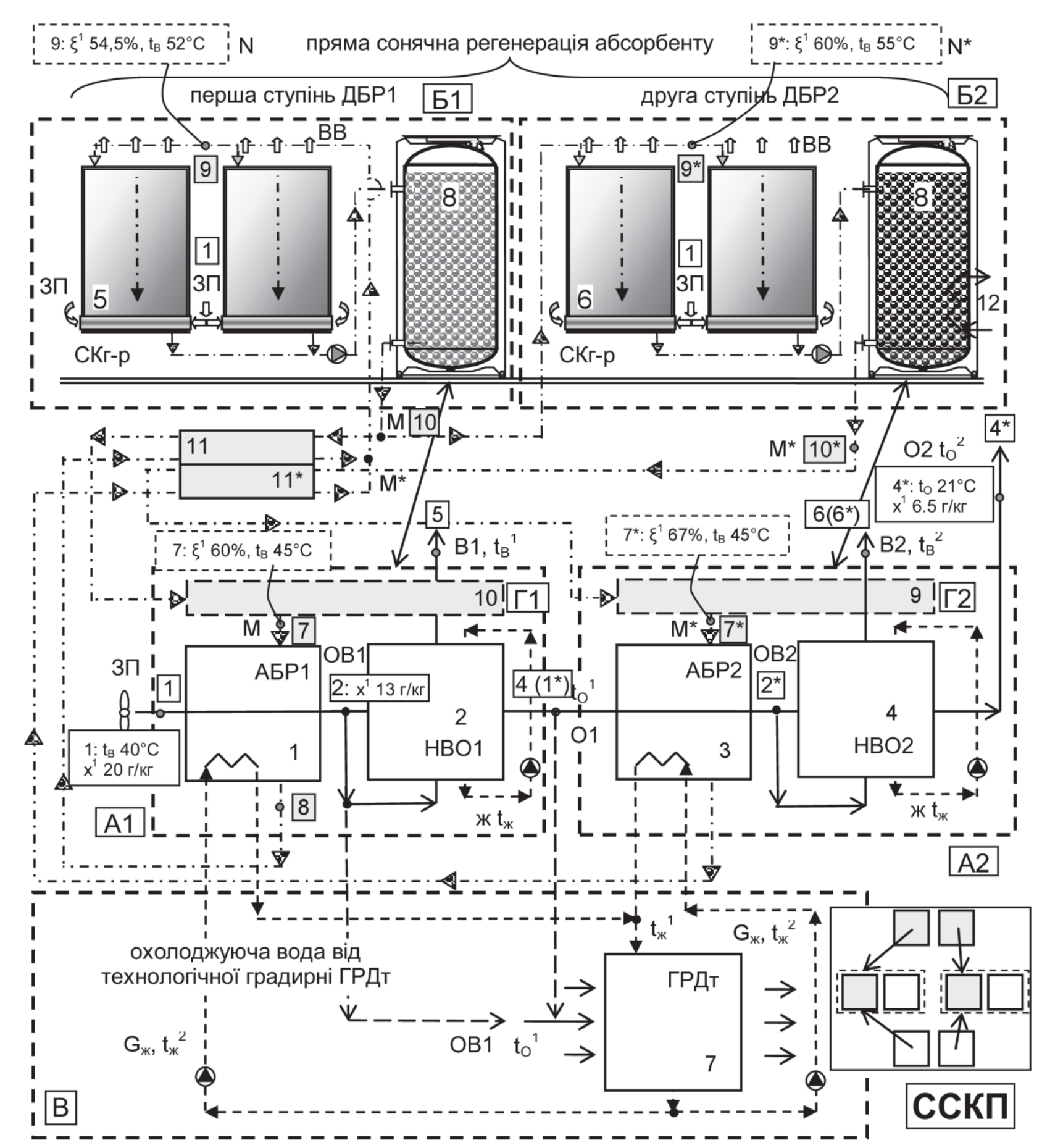

Схемне рімення ССКП (формула АБР - НВО1 - АБР2 - НВО2):

А-Б - використання двоступінчатого десорбера-регенератора, у якому кожна ступінь регенерації абсорбенту (ДБР1 и ДБР2) замкнута на відповідну ступінь абсорбера-осушувача повітря, з послідовним ростом конщентрачії міџного розчину від АБР1 до АБР2

В - використання технологічної градирні ГРДт, одночасно обслуговуючої відповідну ступінь абсорбиії АБР1 и АБР2, при изьому ГРДт праџюєе на частини: 1 - осушенного в АБР1 зовнішнього повітряного потоку і 2 - охолодженого в НВОІ основного повітряного потоку

Рисунок 1 - Принципова схема двоступеневої абсорбційної сонячної системи кондиціювання повітря ССКП (формула АБР1 - НВО1 - АБР2 - НВО2). Позначення наведені у тексті. 
холодних викидних повітряних потоках з НВОг (допоміжний повітряний потік «В») також можуть бути встановлені теплообмінники (наприклад, для охолодження розчину абсорбенту 9 і 10 який входить в АБР, оскільки це потоки холодного, хоч $\mathrm{i}$ зволоженого повітря;

4. У ступенях регенерації абсорбенту можуть використовуватися теплообмінники у місцях де нагріті повітряні потоки «ВВ» залишають СКг-р для попереднього підігріву поступаючого в колектори зовнішнього повітря, що посилить стабільність характеристик процесу регенерації, але дещо збільшить енерговитрати; у другому ступені регенерації (Б2) доцільне використання додаткового джерела нагрівання традиційного типу в бакуакумуляторі (электро- або газовий бойлер 12);

5. В охолоджувальній частині ССКП послідовно використовуються: на першому ступені охолодження повітроохолоджувач непрямого типу НВО1г (2), включений у схему після відповідного ступеня абсорбції; на другому ступені - повітроохолоджувач непрямого типу НВО2г (4); у повітроохолоджувачах обох блоків A1 і А2 осушуватися в абсорбері може тільки допоміжний повітряний потік «В», що надходить у НВОг, що виключає безпосередній контакт основного повітряного потоку «О» з розчином абсорбенту;

6. ССКП може бути побудована 3 використанням автономних градирень технологічного призначення ГРДт (7) для обслуговування абсорберів кожного із ступенів охолодження, або від єдиної ГРДт (рис. 1), що обслуговує абсорбери обох ступенів і працюючої на частині осушеного повітряного потоку в АБР 1, або на частині охолодженого основного повітряного потоку в НВО1г, або на суміші цих потоків (рис. 1, блок В);

7. Усі тепломасообмінні апарати (ТМА) осушувальної й охолоджувальної частини ССКП конструктивно уніфіковані, базуються на використанні апаратів плівкового типу з поперечноточною схемою контактування потоків газу й рідини, що забезпечує: ріст граничних навантажень у газовому потоці, що виключає, до значень швидкостей повітря 6 - 7 м/сек, викликає «затоплення» насадки i високу рівномірність розподілу контактуючих потоків по всьому обсягу насадки [1]; спрощення комунікацій між ТМА й створення «лінійної» схеми побудови систем, що суттєво знижує енерговитрати на організацію руху теплоносіїв.

Розробка конструкції газо-рідинного сонячного колектора-регенератора СКг-р.

Основні типи розроблених плоских сонячних газо-рідинних колекторів СКг-р наведені на рис. 2 . СКг-р є найважливішою частиною системи регенерації (відновлення абсорбенту) і являє собою TMA, у якому рух повітряного потоку забезпечу- ється сонячним розігрівом (різницею щільності повітря на вході й виході 3 робочого каналу СКг-р). Він включає теплоприймач (абсорбер, А), прозоре покриття (ПП) з повітряним зазором між ПП і теплоприймачем (робочим каналом, по якому рухається повітряний потік), і теплоізоляцію дна CK (I3). Прозоре покриття для зниження теплових втрат може виконуватися багатошаровим, а також включати замкнені канали (рис. 2 Б-Д) [1, 2, 9-11].

Теплоприймач СКг-р має U-Образну форму, виконаний 3 алюмінієвого листа із чорновим покриттям поверхні й забезпечує одночасний прогрів як самого повітряного потоку, так і абсорбенту, що стікає у вигляді тонкої плівки по поверхні теплоприймача під впливом сил гравітації. Для підвищення змочуваності розчином абсорбенту поверхня теплоприймача може виконуватися 3 капілярно-пористим покриттям, або 3 регулярною шорсткістю $[1,6]$. Нагрівання повітряного потоку забезпечує його рух через повітряний канал СКг-р; нагрівання абсорбенту забезпечує необхідні умови для реалізації процесу десорбції (видалення води з розчину, - дифузії парів у повітряний потік і виносу водяних парів у навколишнє середовище).

На рис. 2 наведені СКг-р у звичайному й вентильованому (рис. 2Г) варіантах. Багатоканальне розбиття теплоприймача (В) у варіанті СКг-р iз природною циркуляцією повітря забезпечує рівномірність прогріву повітряного потоку й упоряджає його рух у робочому каналі. Це важливо 3 причини малої рушійної сили руху повітря та можливості виникнення значної нерівномірності розподілу повітряного потоку по робочому каналу СКг-р. Для організації руху повітря в запропонованому рішенні використовуються низьконапірні вентилятори тангенціального типу.

Сонячні колектори-регенератори зі примусовою циркуляцією повітря.

СКг-р дуже чутливий до коливань інтенсивності сонячної радіації. Тому інтерес викликає саме вентильований варіант його оформлення. Принципова схема такого конструювання наведена на рис. 2Г. Тут використовується вентилятор тангенціального типу, найбільш зручний для розміщення у вхідній ділянці СКг-р. Вентилятор забезпечує високу рівномірність генерованого повітряного потоку в робочому каналі й характеризується незначним енергоспоживанням. Його витратомірна крива має дуже крутий характер, що підкреслює важливість реального урахування аеродинамічних опорів на ділянках входу й виходу зі СКг-р і опору самого каналу. Найбільш прийнятний вентилятор марки Q4E 100 - АА 3 характеристиками: витрата повітря $\mathrm{G}=1700 \mathrm{~m}^{3} /$ год i $\Delta \mathrm{p}=35$ 45Ра. При цьому швидкість руху повітряного по-

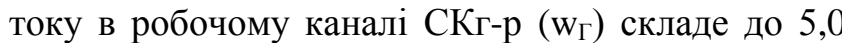


м/с. СКг-р із примусовою циркуляцією повітря може мати додатковий теплообмінник «повітряповітря» на лінії повітряних потоків поступаючого в СКг-р повітря, а також на лінії де повітряний потік виходить з регенератора.

Авторами розроблені варіанти СКг-р для трубчастих i плоских пластинчастих колекторів вертикального розташування $[1,2,9]$. Такі рішення особливо перспективні для багатофункціональних сонячних систем. Варіанти СКг-р із двозахідними теплоприймачами (рис. 2Д и Е), забезпечують попередній прогрів абсорбенту перед його вступом у безпосередній контакт із повітряним потоком. Розроблені СКг-р 3 варіювальним числом трубчастих теплоприймачів i теплоприймачем у вигляді багатоканальної плити.

Інтерес представляють перспективні напрямки розробок СКг-р вертикального розташування 3 використанням у якості теплоприймача (абсорбера) труби або багатоканальної плити 3 мікропористої кераміки. Це забезпечує стовідсоткову змочуваність поверхні теплоприймача стікаючою плівкою абсорбенту, у якому дифузія водяних пар здійснюється через пористу стінку теплоприймача (у двозахідному варіанті СК). Одночасно вирішується й проблема 3 каплевинесенням, а також знижується аеродинамічний опір робочого каналу в цілому, через відсутність плівки рідини на поверхні теплоприймача. Обидва рішення вимагають подальшого аналізу.

СКг-р, як і звичайний СКж, орієнтований на південь, може встановлюватися вертикально, або під певним кутом до горизонтальної поверхні для максимального приймання сонячної енергії, з урахуванням характеру системи: $\beta=\varphi$ для цілорічних геліосистем і $\beta=\varphi-15^{\circ}$ для сезонних геліосистем (період експлуатації квітень - жовтень). Уточнення величини цього кута, необхідне для максимального вловлювання падаючої на поверхню СКг-р сонячної енергії, наведене в роботі А.В. Дорошенко [1].

У колекторах СКг-p (Scg-lq) прозоре покриття (ПП) виконане 3 полімерної багатоканальної плити, що має стільникову структуру (рис. 3 Б-Е). Така плита може розглядатися як звичайне подвійне прозоре покриття, утворене двома рівновіддаленими розташованими полімерними пластинами 3 повітряним зазором між ними, а сам СК, таким чином, являє собою сонячний колектор 3 подвійним прозорим покриттям. Добре відомо, що використання подвійного ПП суттєво знижує величину сумарного коефіцієнта втрат як у традиційному рідинному СКж, так і в СКг-р [1], але зазвичай застосовуване подвійне засклення приводить до росту ваги й габаритів СК і ускладнює конструкцію колектора в цілому. Використання багатоканальної полімерної плити практично не змінює ці показники, виконуючи в той же час традиційну роль «подвійного засклення» [1]. Плити прозорого покриття ПП у СКг-р для підвищення жорсткості виробу розташовані перпендикулярно ребрамперегородкам теплоприймаючого каналу. Ширина робочого каналу $\delta_{1-1}$ становила $1000 \mathrm{Mм}$, при варійованій висоті $\delta_{1-2}=100-150$ мм в обох варіантах СКг-р. Для вентильованого варіанта СКг-р рівень сумарних теплових втрат трохи зростає, порівняно 3 варіантом із природньою тягою, що зумовлене ростом конвективних втрат $[1,9]$.

\section{2. Оптимізація геометричних і режимних параметрів газо-рідинних сонячних колек- торів.}

У цьому розділі описується математичне моделювання СКг-р, прозоре покриття (ПП) якого виконано 3 полімерної багатоканальної плити зі стільниковою структурою 3 полімерних пластин 3 повітряним зазором між ними (рис. 2Г). Розподіл температур кожного елемента СКг-р, включаючи теплоносії, визначаємо на підставі рівнянь теплового балансу. При виводі рівнянь, зроблені допущення: режим роботи сонячного колектора стаціонарний; градієнтом температури теплоносіїв по периметру каналу можна знехтувати; температура кожного елемента СКг-р змінюється тільки за напрямом руху теплоносія; властивості матеріалів колектора й теплоносіїв не залежать від температури; поглинання сонячної енергії покриттями колектора не впливає на втрати колектора в цілому. Коефіцієнти тепловіддачі (їх радіаційні та конвективні складові) можна розрахувати по відомих рівняннях [1]. Для зовнішньої поверхні колектора 3 боку сонця (покриття ВП-ОС, тут індекси: НБ для небозводу; ОС - для оточуючого середовища, ВП - для верхнього прозорого покриття), можна використати залежності:

$$
\begin{aligned}
& \mathrm{q}_{n n-6 n}=\left(\alpha^{\mathrm{k}}{ }_{n n-6 n}+\alpha^{p}{ }_{n n-6 n}\right) \cdot \mathrm{F}_{c \kappa} \cdot\left(T_{n n}-T_{\theta n}\right)=\left(T_{n n}-T_{\theta n}\right) / \mathrm{R}_{4} \\
& \alpha^{\mathrm{k}}{ }_{n n-B n}=\left[1-0.0018 \cdot\left(T_{n n} / 2+T_{\text {вn }} / 2\right)\right] \text {. } \\
& \cdot\left[1-\left(\beta-45 \cdot\left(0.00259-0.00144 \cdot \varepsilon_{6 n}\right)\right] \cdot 1.14 \cdot\left(T_{n n}-T_{6 n}\right)^{0.31} / \delta_{\text {нn- } 8 n}^{0.07}\right.
\end{aligned}
$$




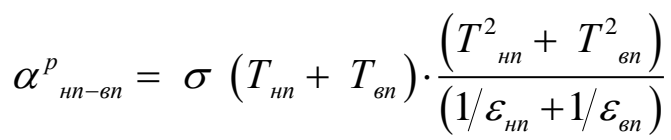

$$
\begin{aligned}
& \mathrm{q}_{a-H n}=\left(\alpha_{a-H n}^{\mathrm{k}}+\alpha_{a-H n}^{p}\right) \cdot \mathrm{F}_{c \kappa} \cdot\left(T_{a}-T_{H n}\right)=\left(T_{a}-T_{H n}\right) / \mathrm{R}_{3} \\
& \alpha_{a-\mu n}^{\mathrm{k}}=\left[1-0.0018 \cdot\left(T_{a} / 2+T_{n n} / 2\right)\right] \cdot\left[1-\left(\beta-45 \cdot\left(0.00259-0.00144 \cdot \varepsilon_{n n}\right)\right]\right. \text {. } \\
& \cdot 1.14\left(T_{a}-T_{\text {ни }}\right)^{0.31} / \delta_{a-н n} 0.07
\end{aligned}
$$

у залежності від величини $\mathrm{w}_{\text {пов. }}$

$$
\begin{gathered}
\alpha_{a-\text { }}^{\mathrm{k}}=\left(5,7+\mathrm{w}_{\text {пов. }}\right) \\
\alpha_{a-\text { मи }}^{p}=\sigma \cdot\left(T_{a}+T_{H n}\right) \cdot \frac{\left(T_{a}^{2}+T_{H}^{2}\right)}{\left(1 / \varepsilon_{a}+1 / \varepsilon_{\text {ни }}\right)}
\end{gathered}
$$

де $\beta$ - кут нахилу СКг-р до горизонту, градуси; $\delta_{\mathrm{a}-}$ нп - відстань між відповідними поверхнями, мм.
Залежно від типу СКг-р, 3 «природною» тягою, забезпечуваною сонячним прогрівом повітря або з вентилятором, розташованим на подачі повітря в колектор, у системі рівнянь (3) слід використовувати одне із двох наведених рівнянь для розрахунків величини $\alpha_{\mathrm{ka-н}}$. Для теплоізоляції $(A-3)$ термічний опір $\mathrm{R}_{1}$ визначається теплопровідністю обраного матеріалу теплоізоляції. Для зовнішньої поверхні колектора з боку дна $(I 3-O C)$ можна використати наступні формули:

$$
\begin{gathered}
\mathrm{q}_{i 3-o c}=\left(\alpha^{\mathrm{k}}{ }_{i 3-o c}+\alpha^{p}{ }_{i 3-o c}\right) \cdot \mathrm{F}_{c \kappa / p} \cdot\left(T_{i 3}-T_{o c}\right)=\left(T_{i 3}-T_{o c}\right) / \mathrm{R}_{2} \\
\alpha^{\mathrm{k}}{ }_{B n-o c}=\left(5,7+\mathrm{w}_{n o b .}\right) \\
\alpha^{p}{ }_{i 3-o c}=\varepsilon_{n} \cdot \sigma \cdot\left(T_{i 3}+T_{i 3}\right) \cdot\left(T^{2}{ }_{i 3}+T_{o c}^{2}\right) \cdot\left[\left(T_{i 3}-T_{o c}\right) /\left(T_{i 3}-T_{\mu б}\right)\right]
\end{gathered}
$$

де $\alpha_{a-\infty}^{\mathrm{k}}, \alpha_{a-n n}^{\mathrm{k}}, \alpha^{\mathrm{k}}{ }_{n n-8 n}, \alpha^{\mathrm{k}}{ }_{\theta n-o c}, \alpha^{\mathrm{k}}{ }_{i 3-o c}-$ конвективні складові тепловіддачі $\mathrm{BT} /\left(\mathrm{M}^{2} \cdot \mathrm{K}\right)$; $\alpha_{a-4 n}^{p}, \alpha^{p}{ }_{n n-6 n}, \alpha^{p}{ }_{\text {} n-o c}, \alpha^{p}{ }_{i 3-o c}-$ радіаційні складові теплових втрат Вт/( $\left.\mathrm{M}^{2} \cdot \mathrm{K}\right)$.

Термічні опори основних елементів СКг-р визначають коефіцієнт втрат за формулою $\mathrm{U}_{\mathrm{i}}=1 / \mathrm{R}_{\mathrm{i}}$, де $\mathrm{U}_{\mathrm{i}}-$ коефіцієнт втрат на кожній ділянці $\mathrm{CK}, \mathrm{BT} /\left(\mathrm{m}^{2} \cdot \mathrm{K}\right)$; Ri - термічний опір на кожній ділянці СК, $\left(\mathrm{M}^{2} \cdot \mathrm{K}\right) /$ Вт. Величина сумарного коефіцієнта втрат для СКг-р визначається за формулою:

$$
\begin{array}{r}
\mathrm{U}_{\Sigma}=1 /\left(\mathrm{R}_{1}+\mathrm{R}_{2}+\mathrm{R}_{3}+\mathrm{R}_{4}+\mathrm{R}_{5}\right) \\
U_{\Sigma}=\frac{1}{\frac{1}{\alpha^{k}{ }_{b n-o c}+\alpha_{\theta n-o c}^{p}}+\frac{1}{\alpha_{n n-6 n}^{k}+\alpha_{n n-6 n}^{p}}+\frac{1}{\alpha_{a-n n}^{k}+\alpha_{a-H n}^{p}}}+\frac{\lambda_{i 3}}{\delta_{i 3}}
\end{array}
$$

Основне значення, при правильному виборі типу й розрахунків товщини теплоізоляції, мають термічні опори на ділянках $\mathrm{R}_{3}, \mathrm{R}_{4} \mathrm{i} \mathrm{R}_{5}$ які визначають теплові втрати колектора-регенератора.

На рис. 3 наведені результати розрахунків коефіцієнта теплових втрат для розробленого СКг-р у вентильованому варіанті. Зі збільшенням товщи- ни теплоізоляції $\delta_{3}$ коефіцієнт теплових втрат монотонно зменшується. Як видно, використовувати СКг-р з товщиною теплоізоляції $\delta_{\text {iз }}>40$ мм недоцільно, тому що при цьому $\mathrm{U}_{\Sigma}$ зменшується малоістотно, а матеріальні витрати й габарити колектора суттєво зростають.

Серйозний практичний інтерес становить оцінка впливу швидкості вітру над поверхнею прозорого покриття СК (певною мірою й під дном СК, але тут цей вплив зменшується за рахунок правильно розрахованої теплоізоляції) на коефіцієнт теплових втрат, а також на к.П.д. СК (рис. 3). При зміні $\mathrm{w}_{\Gamma}$ від 0 до $5 \mathrm{~m} / \mathrm{c}$, величина $\mathrm{U}_{\Sigma}$ збільшується найбільш суттєво (на 20-30\%). Із цього випливає, що всупереч існуючим рекомендаціям, швидкість вітру необхідно враховувати при розрахунках СК і сонячних систем у цілому.

\section{3. Аналіз можливостей розроблених соня- чних систем ССКП}

Аналіз принципових можливостей розроблених сонячних систем був розглянутий на прикладі двоступінчастої ССКП із одним (єдиним для двох ступенів) десорбером, розробленої по формулі: (ДБР $1 \leftrightarrow$ АБР 1) - HВО1 - (ДБР1 ↔ АБР2) - HВО2 $\rightarrow$ «॥ (рис. 4А) і ССКП із двома десорберами 
розробленої по формулі: (ДБР1 $\leftrightarrow$ АБР1) - НВО1 - (ДБР2 ↔ АБР2) - НВО2 $\rightarrow$ «О» (рис. 4Б). 3ображення процесів у ССКП зображено на сполученій діаграмі $\mathrm{p}$ - $\mathrm{T}$ для розчину $\mathrm{LiBr}+-$ вологе повітря (рис. 4). Показані: 1-2 і $1 *-2 *$ - процеси осушення повітря в ступенях абсорбера АБР1 і АБР2; $2-4\left(1^{*}\right)$ (основний повітряний потік) і 2-5 (допомі- жний повітряний потік) - процеси у випарному охолоджувачі непрямого типу $\mathrm{HBO} 1 ; 2 *-4 *$ i 2 *-6$6^{*}$ - процеси у випарному охолоджувачі непрямого типу $\mathrm{HBO} 2 ; 7-8(8 *)-9-10$ - процеси зміни стану розчину абсорбенту в абсорбері (7-8, АБР1), (7-8*, АБР2) теплообміннику (8-9, 8*-9 і 10-7) та десорберi (9-10).

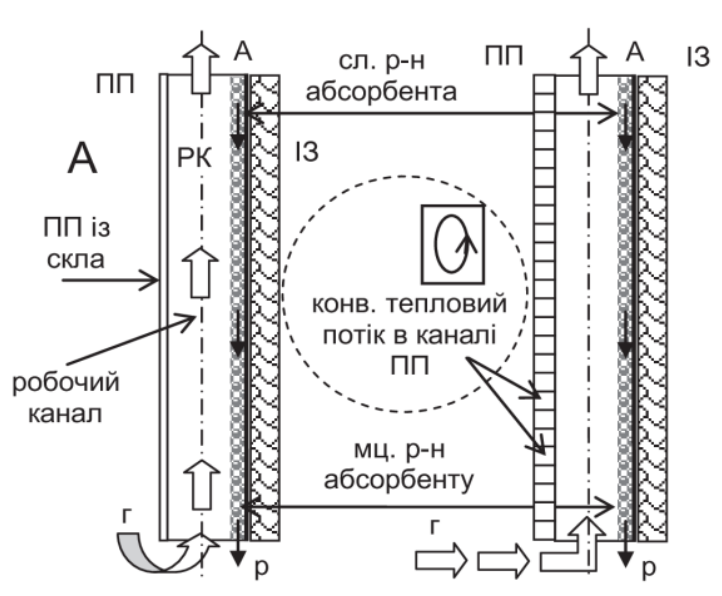

CKr-p
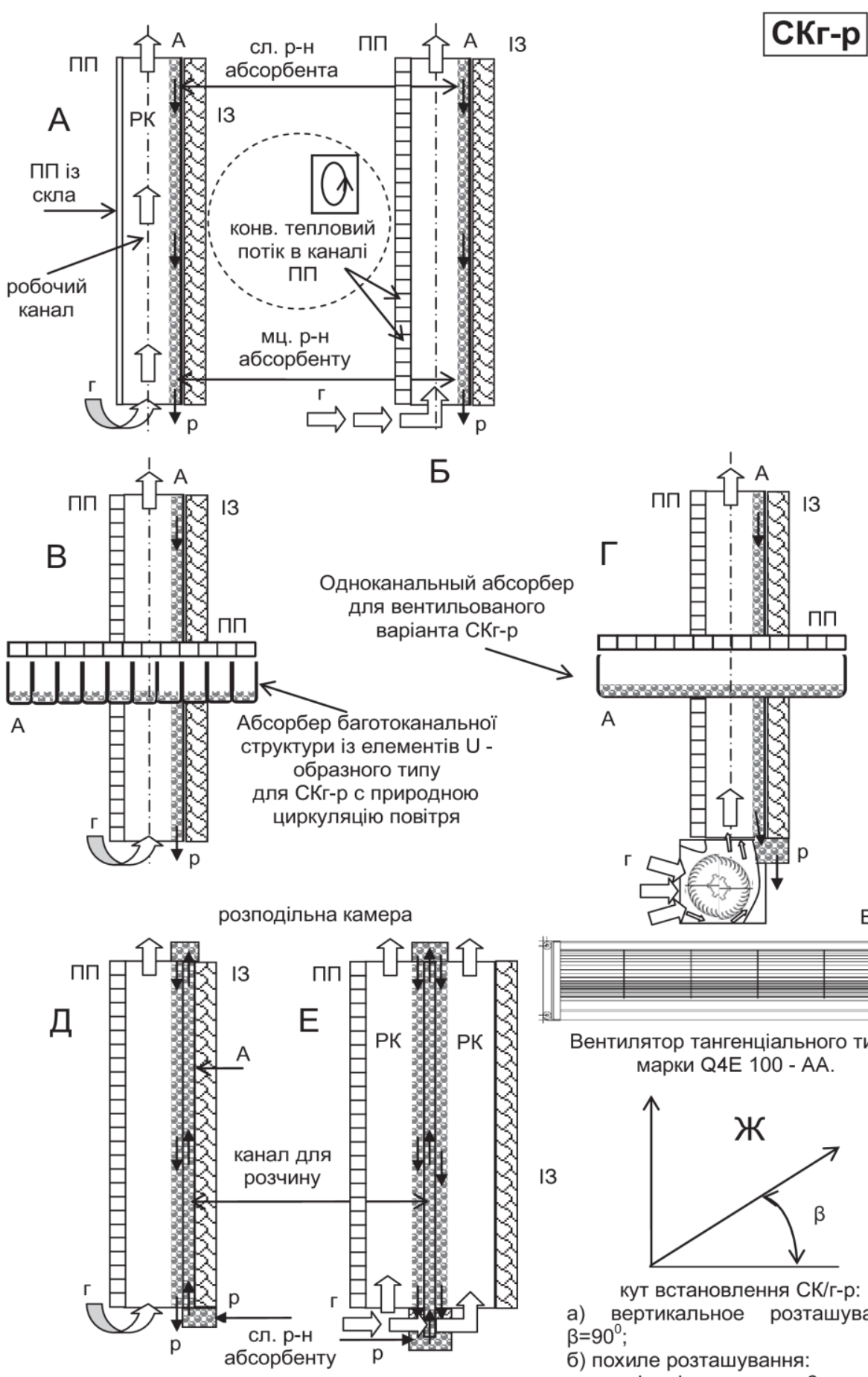


\section{Вентилятор марки Q4E 100-CC01-02}

Температура прозорого покриття: $45^{\circ} \mathrm{C}$ Середня температура абсорбера: $60{ }^{\circ} \mathrm{C}$

Температура зовнішнього середовища: $28^{\circ} \mathrm{C}$

Висота робочого каналу: 92 мм

Витрата газу (повітря): $900-1300 \mathrm{~m}^{3} /$ год
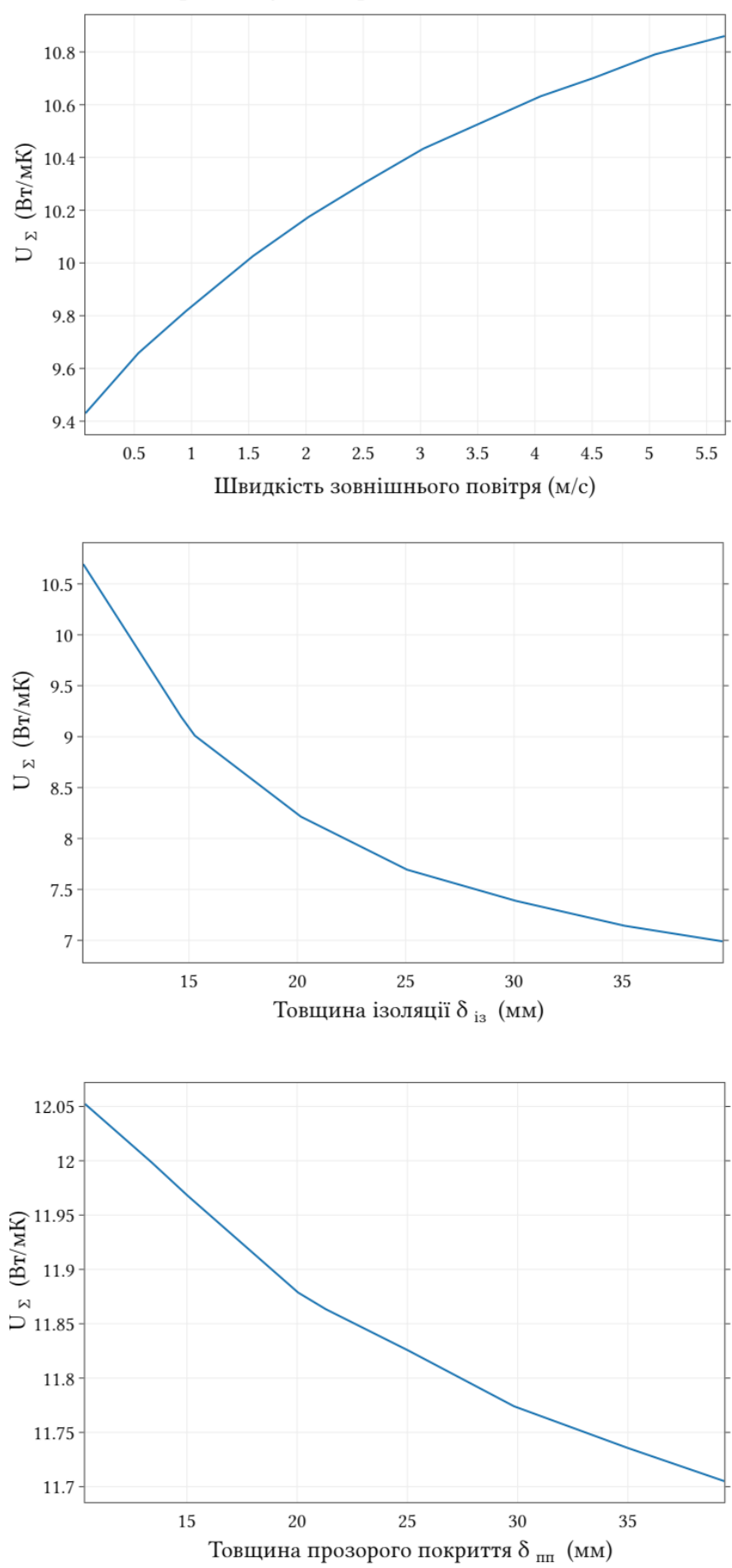

\section{Вентилятор марки Q4E 100-ВС01-02}

Температура прозорого покриття: $45^{\circ} \mathrm{C}$ Середня температура абсорбера: $60{ }^{\circ} \mathrm{C}$

Температура зовнішнього середовища: $28^{\circ} \mathrm{C}$ Висота робочого каналу: $92 \mathrm{Mм}$

Витрата газу (повітря): $1000-1200 \mathrm{~m}^{3} /$ год
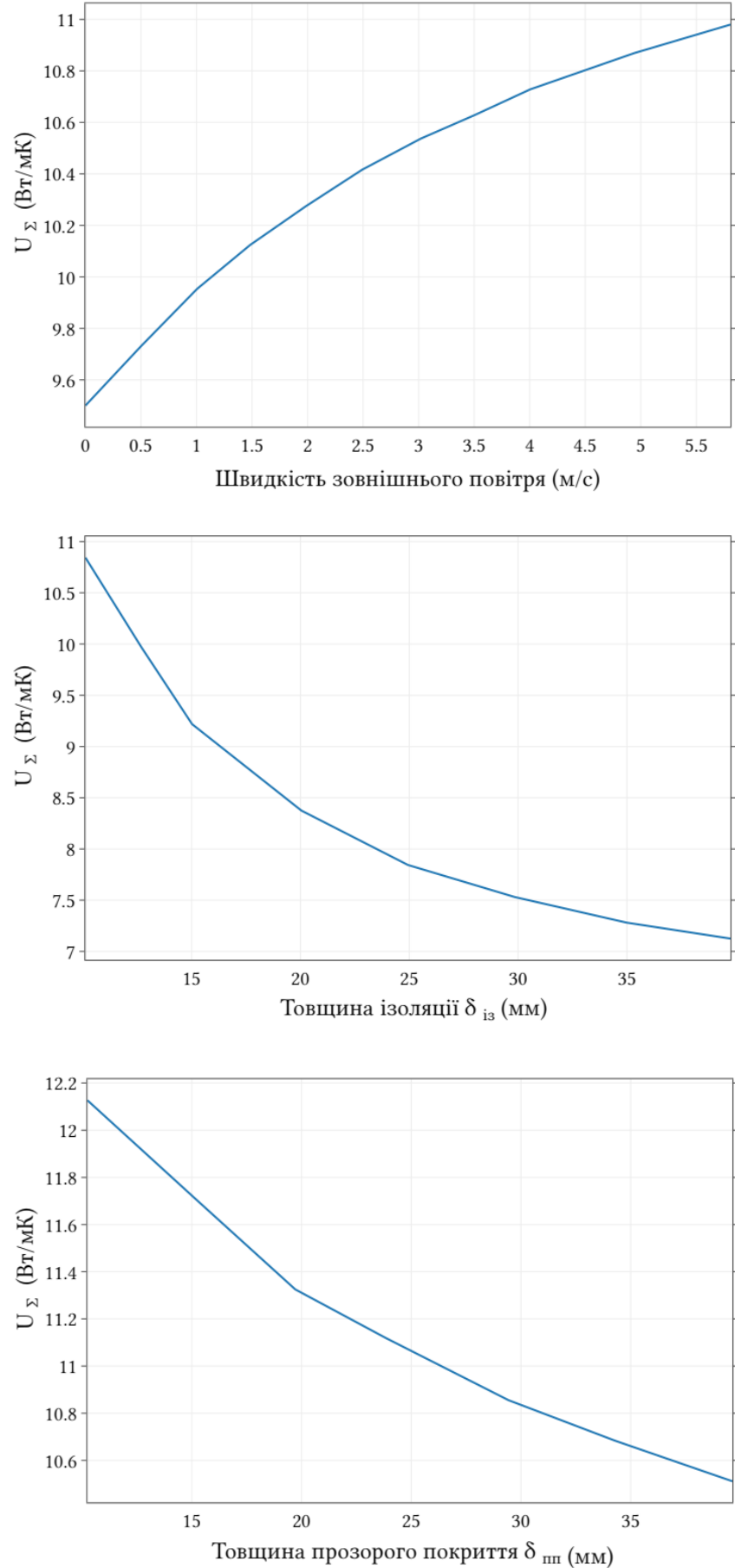

-Результати розрахунків коефіцієнта теплових втрат для розробленого СКг-р в вентильованому варіанті.

Оскільки мова йде про створення систем, що забезпечують комфортні параметри для людей у приміщенні, важливим поняттям є визначення вимог до таких систем 3 точки зору забезпечення цих параметрів. Основним показником мікроклімату є: температура в характерних зонах приміщень, вологість і гігієнічний стан повітря. Температура й вологість, їх максимальні розрахункові значення, коливання й зміни протягом доби й протягом року є найважливішими факторами, що впливають на людей, що перебувають у приміщенні. Деяке значення має також швидкість руху повітря в приміщенні. Основне завдання ССКВ - подача в, що обслуговується приміщення необхідної кількості свіжого повітря 3 температурою й вологістю, що забезпечують комфортні термовологісні параметри для житлових і суспільних 
приміщень.
Відпові- дно до існуючих стандартів зона оптимальних термовологісних параметрів для теплого (літнього) періоду року обмежена ізотермами 20 і $25^{\circ} \mathrm{C}$ i лініями $=30 \%$ і 60\% (на рис. 4 зона виділена сірим кольором).
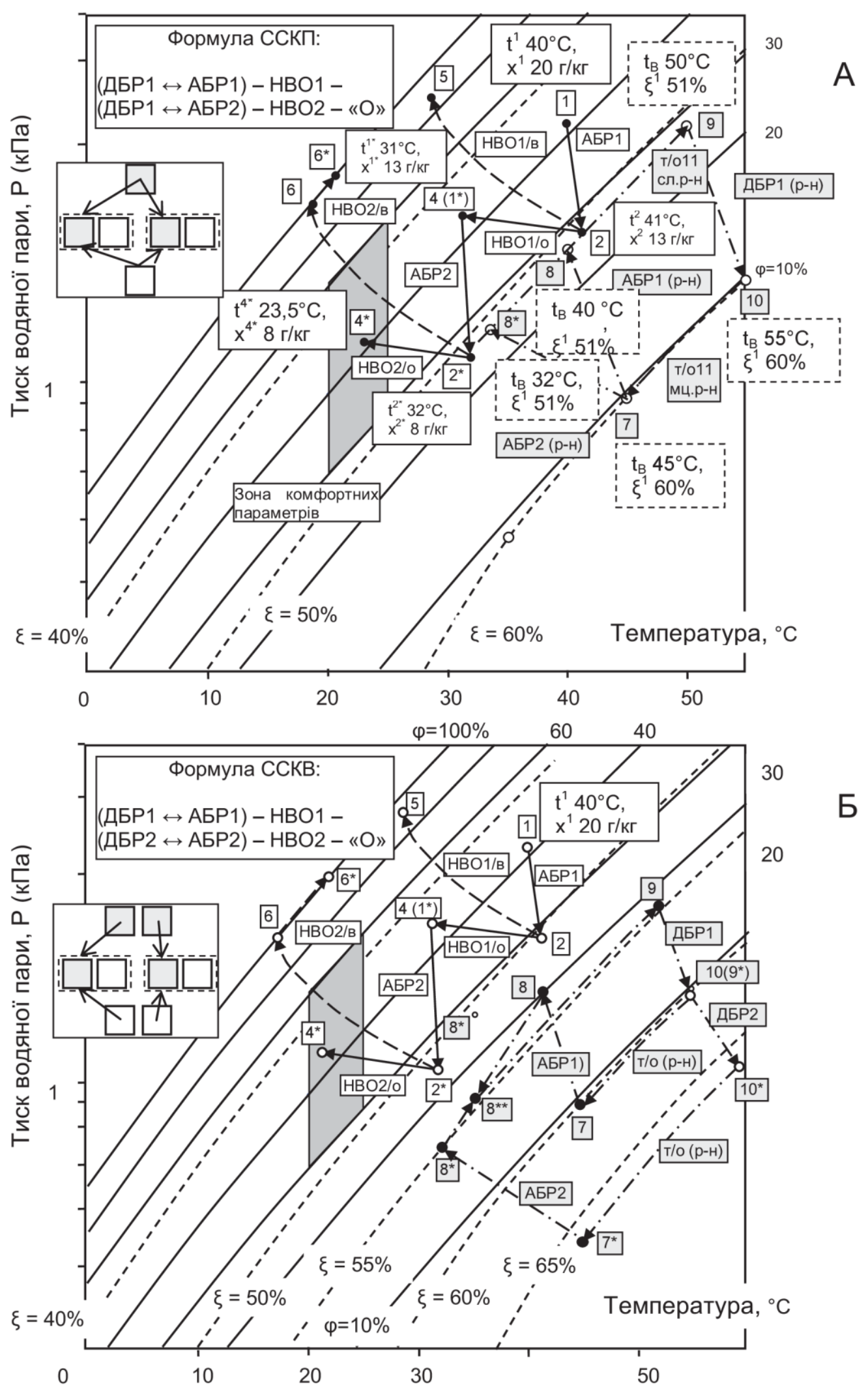
Рисунок 4 - Процеси в ССКП на диаграмі p-Т (розчин $\mathrm{LiBr}+-$ вологе повітря)Стандартом обумовлена й розширена комфортна зона із припустимими параметрами: ізотермами 18 і $28^{\circ} \mathrm{C}$, ліворуч кривою $\left(=30 \%\right.$, праворуч ламаною лінією з характерними точками $\left({ }^{\circ} \mathrm{C}^{\circ} \mathrm{C}^{\circ} \mathrm{C}{ }^{\circ} \mathrm{C}\right.$ ССКП із одним (єдиним для двох ступенів) десорбером. Початкові умови для зовнішнього повітря були прийняті в найважчому варіанті, як за його температурою $-\left(\mathrm{t}^{1}=40^{\circ} \mathrm{C}\right)$, так і за вологоємністю $\left(\mathrm{x}^{1}=20\right.$ г/кг), щоб наочно виявити граничні можливості розроблювальних ССКП. Всі результати отримані на основі виконаного теоретичного й експериментального досліджень авторів [1-12], опираючись на залежності ефективності процесів від визначальних параметрів (витрати газу й рідини в ТМА осушувального й охолоджувального контурів і початкові температури й вологоємність контактуючих потоків, а також концентрацію розчину абсорбенту). Отримано (послідовно по ступенях ССКП):

1: $3 \Pi: \mathrm{t}^{1} 40^{\circ} \mathrm{C}, \mathrm{t}_{\mathrm{M}}^{1} 28^{\circ} \mathrm{C}, \mathrm{t}_{\mathrm{P}}{ }_{\mathrm{P}} 25^{\circ} \mathrm{C}, \mathrm{x}^{1} 20$ г/кг;

2: АБР 1 : $\left(\xi^{1} 60 \%-51 \%\right), \mathrm{t}^{2} 41^{\circ} \mathrm{C}, \mathrm{x}^{2} 13$ г/кг;

3: HBO1 (основний повітряний потік): $\mathrm{t}^{4} 31^{\circ} \mathrm{C} ; \mathrm{x}^{2} 13$ г/кг; допоміжний повітряний потік: $\mathrm{t}^{5} 29,5^{\circ} \mathrm{C}, \varphi$ $86 \%$;

4: АБР2: ( $\left.\xi^{1} 60 \%-51 \%\right), \mathrm{t}^{2^{*}} 32^{\circ} \mathrm{C}, \mathrm{x}^{2 *} 8$ г/кг;

5: HBO2 (основний повітряний потік): $\mathrm{t}^{4} 23,5^{\circ} \mathrm{C} ; \mathrm{x}^{2^{*}} 8$ г/кг; допоміжний повітряний потік: $\mathrm{t}^{5} 21$ $22,5^{\circ} \mathrm{C}, \varphi 100 \%$ (можлива реконденсація у допоміжному повітряному потоці)

Перший ступінь абсорбера забезпечує зниження вологовмісту від 20 до 13 г/кг, другий - до 8 г/кг. Температура осушуваного в абсорбера повітряного потоку трохи зростає. Це визначається оптимізацією енерговитрат на охолодження відповідного абсорбера ( по ступенях охолоджувача), на привід вентилятора й рідинних насосів, у першу чергу мова йде про градирню технологічного призначення, що обслуговує відповідний абсорбер. У схемі (рис. 1) використовується одна спільна для обох ступенів градирня ГРДт.Температура допоміжного потоку повітря трохи нижче, ніж у основного, але його відносна вологість, особливо зі зниженням загального температурного рівня при переході до другого ступеня охолодження, практично рівна 100\% (лінія процесу $2 *-6-6 *$ ). Тут існує небезпека повного насичення повітряного потоку ще до його виходу з насадки ТМА й різкого зниження ефективності охолодження як по основному, так і по допоміжному повітряних потоках. Вирішення цього завдання лежить у перерозподілі співвідношення витрат $1=\mathrm{G}_{\mathrm{o}} / \mathrm{G}_{\mathrm{B}}$. Для першого ступеня охолодження (НВО1г) може бути прийняте зна-

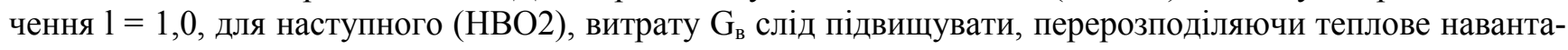
ження на «суху» $\mathrm{i}$ «мокру» частини НВОг. Досягнутий рівень охолодження $\mathrm{t}_{\mathrm{o}}=23,5^{\circ} \mathrm{C} \epsilon$ нижчим за природну межу охолодження по зовнішньому повітрю $\left(\mathrm{t}^{1}{ }_{\mathrm{M}}=28^{\circ} \mathrm{C}\right)$ і навіть нижче його точки роси $\left(\mathrm{t}_{\mathrm{P}}{ }_{\mathrm{P}}=\right.$ $\left.25^{\circ} \mathrm{C}\right)$. Для дуже важких параметрів зовнішнього повітря розроблена ССКП однозначно забезпечує одержання необхідних комфортних параметрів повітряного середовища в приміщенні, що обслуговується. На сполученій діаграмі показані також процеси зміни стану розчину абсорбенту в абсорберах по ступенях охолоджувача (7-8, АБР1) і (7-8*, АБР2), теплообміннику (8-9, 8*-9 і 10-7) і десорбері-регенераторі (9-10, ДБР). Потоки слабкого розчину абсорбенту по ступенях АБР1 і АБР2 мають різну температуру (насправді й концентрація абсорбенту в них трохи відрізняється) і змішуються перед теплообмінником.

Двоступінчаста ССКП із двома десорберами, розроблена по формулі (ДБР1 $\leftrightarrow$ АБР1) - НВО1 (ДБР2 $\leftrightarrow$ АБР2) - НВО2 $\rightarrow$ «О» (рис. 1 і 4Б). Оптимальне використання двоступінчастого варіанта десорбера, коли кожний його ступінь забезпечує подальше зростання концентрації абсорбенту й поєднана в роботі з відповідним ступенем абсорбера. Отримано (послідовно по ступенях ССКП), рис. 4Б:

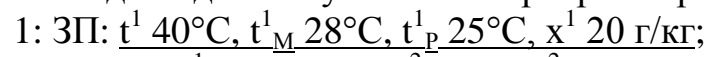

2: АБР $1:\left(\xi^{1} 60 \%-53 \%\right), \mathrm{t}^{2} 41^{\circ} \mathrm{C}, \mathrm{x}^{2} 13$ г/кг;

3: НBO1, основний повітряний потік: $\mathrm{t}^{4} 30^{\circ} \mathrm{C} ; \mathrm{x}^{2} 13$ г/кг; допоміжний повітряний потік: $\mathrm{t}^{5} 28,5^{\circ} \mathrm{C}, \varphi$ $86 \%$;

4: АБР2: ( $\left.\xi^{1} 67 \%-55 \%\right), \mathrm{t}^{2 *} 32^{\circ} \mathrm{C}, \mathrm{x}^{2 *} 6,5$ г/кг;

5: НBО2, основний повітряний потік: $\mathrm{t}^{4} 21,0^{\circ} \mathrm{C} ; \mathrm{x}^{2 *} 6,5$ г/кг; допоміжний повітряний потік: $\mathrm{t}^{5} 20,0^{\circ} \mathrm{C}$, $\varphi$ 100\% (можлива реконденсація у допоміжному повітряному потоці)

У розроблених рішеннях досягнутий більш глибокий рівень охолодження, ніж у випадку схеми 3 одним десорбером, $\mathrm{t}_{\mathrm{o}}=21,0^{\circ} \mathrm{C}$. Показано, що для дуже важких параметрів зовнішнього повітря розроблена ССКП однозначно забезпечує одержання необхідних комфортних параметрів повітряного середовища в приміщенні, що обслуговується. Число необхідних ступенів охолодження [(ДБР ↔ АБР) - НВО] в охолоджувачі ССКП визначається ступенем труднощів вирішуваного завдання, i, наприклад, для умов України і Європи в цілому, можна обійтися одноступінчастим варіантом ССКП.

\section{Висновки}


1. Використання в осушувальній частині ССКП багатоступеневого абсорбера для осушення повітряного потоку, як і використання багатоступеневого десорбера для відновлення концентрації абсорбенту, з послідовним ростом концентрації абсорбенту по ступенях осушувальних блоків, забезпечує ріст ефективності процесу абсорбції й істотне зниження меж наступного випарного охолодження середовищ (газів або рідин).

2. Виконаний аналіз принципових можливостей розроблених ССКП, показав, що навіть для дуже важких параметрів зовнішнього повітря, ССКП однозначно забезпечує одержання необхідних комфортних параметрів повітряного середовища в приміщенні, що обслуговується, без залучення традиційної парокомпресорної техніки; число необхідних ступенів охолодження [(ДБР $\leftrightarrow$ АБР) - НВО] в охолоджувачі ССКП визначається ступенем труднощів вирішуваного завдання, i, наприклад, для умов України і Європи в цілому, можна обійтися одно- або двоступінчастим варіантом ССКП;

3. Досягнутий рівень охолодження основного повітряного потоку в $\mathrm{HBO}, \mathrm{t}_{\mathrm{o}}=23,5^{\circ} \mathrm{C}$, виявляється нижче природної межі охолодження за зовнішнім повітрям $\left(\mathrm{t}_{\mathrm{M}}^{1} 28^{\circ} \mathrm{C}\right)$ і навіть нижче його точки роси $\left(\mathrm{t}_{\mathrm{P}}^{1} 25^{\circ} \mathrm{C}\right)$; перехід до двоступінчастої ССКП із двома десорберами (за формулою (ДБР1 $\leftrightarrow$ АБР1) - НВО1 - (ДБР2 ↔ АБР2) - НВО2) приводить до подальшого зниження рівня охолодження $\left(\mathrm{t}_{\mathrm{o}}=21,0^{\circ} \mathrm{C}\right)$

\section{Література}

1. Doroshenko A.V., Glauberman M.A. Alternative energy. Refrigerating and Heating Systems, [Odessa I.I. Mechnicov National University Press], Odessa, 2012.

2. Doroshenko A., Silich S. Heat-cooling multifunction solar systems. Problemele energeticii regionale, Moldova, Academia de Stiinte, Institutul de Energetica, 2010, no. 3(14), pp. 44-52. (In Russian)

3. Chen G.M., Zheng J., Doroshenko A., Shestopalov K. Design and modeling of a collectorregenerator for solar liquid desiccant cooling system. "International Sorption Heat Pump Conference", Washington, 2014.

4. Doroshenko A., Shestopalov K., Khliyeva O. Development of new schematic solutions and heat and mass transfer equipment for alternative solar liquid desiccant cooling systems. "International Sorption Heat Pump Conference", Washington, 2014.

5. Chen G.M., Doroshenko A.V., Shestopalov K.O., Khliyeva O.Y. Evaporative coolers of water and air for cooling systems. Analysis and perspectives, Hangzhou, August 31-September 2, 2014 [11th IIR Gustav Lorentzen Conference on Natural Refrigerants, 2014].

6.Chen G.M., Doroshenko A.V., Koltun P., Shestopalov K.O. Comparative field experimental investigations of different flat plate solar collectors, Solar Energy, 2015, no. 115, pp. 577-588.

7. Chen G.M., Shestopalov K.O., Doroshenko A.V., Koltun P. Polymeric materials for solar energy utilization: a comparative experimental study and environmental aspects. Polymer-Plastics Technology and Engineering, 2015, Submitted paper.

8. Дорошенко А.В. Солнечные многоступенчатые абсорбционные холодильные системы на основе тепломасообменных аппаратов пленочного типа // А.В. Дорошенко, А.Р. Антонова, К.В. Людницкий / Холодильная техника и технология. 2015. - 51(2) - C. 25-31.

9. Антонова, А. Р. Теоретичне та експериментальне дослідження процесів у газорідинних сонячних колекторах-регенераторах альтернативних холодильних систем : дис. канд. техн. наук, 05.14.06, захищена 29.09.2014, затвердж. 25.11.2014 / Альфія Раісівна Антонова. - Одеca, 2014. -205 c.

10. Дорошенко А.В., Антонова А.Р. Глауберман М.А. Изучение течения тонкого слоя вязкой жидкости по наклонной поверхности в канале с газовым потоком. Научный сборник «Физика аэродисперсионных систем». Вып. 48, 2011, с. 25-34. 11. Антонова А.P., Кириллов В.X. Теоретическое экспериментальное изучение пленочных течений в тепломассобменных аппаратах (испарительных охладителях, газо-жидкостных солнечных колекторах-регенераторах) энергетических систем. «Холодильная техника и технология» ОГАПТ, №2(142), 2013, c. 20-28

12. Doroshenko A.V., Antonova A.R., Garh Saed. Multifunctional Solar Systems based on two-stage absorbent solution Regeneration. Problemele energeticii regionale, Moldova, Academia de Stiinte, Institutul de Energetica, 2010, 1 (27), 2015. pp. 44-52. (In Russian)

Отримана в редакції19.02.2019, прийнята до друку 02.04.2019 


\title{
Solar absorption air conditioning systems based on two-step absorbent regeneration
}

\author{
Doroshenko A.V., Antonova A.R., Bodnia A. Khalak V.F. \\ Odessa National Academy of Food Technologies, Ukraine
}

\begin{abstract}
Conceptual designs have been developed for multifunctional solar air dehumidification systems, heat supply (hot water supply and heating), cold supply and air conditioning based on an open absorption cycle with direct regeneration of the absorbent. Such systems are based on pre-drying of the air flow and subsequent evaporative cooling of media in solar refrigeration systems (SRS) and thermal and humid air treatment in solar air conditioning systems (SACS). The authors used the principle of two-stage regeneration of the absorbent. The solar system consists of autonomous dehumidifying and cooling units, with each regeneration stage closed to the corresponding stage of the air absorber stage (air dryer), which allows increasing the concentration of the absorbent from stage to stage (in the range of possible concentrations of the LiBr lithium bromide solution used). Fundamental solutions have been developed for the new generation of gas-liquid solar collectors, which make it possible to exclude the desorber (absorbent solution regenerator) from the concept of the solar system, providing direct regeneration of the absorbent solution.. The work of heat and mass transfer apparatus, which are included in the drying and cooling circuits of absorption systems, is based on the principle of film interaction of gas and liquid flows using a multichannel packed structure of polymeric materials. A preliminary analysis of the capabilities of multifunctional solar absorption systems was carried out on the basis of the experimental data of the authors and the modeling of heat and mass transfer processes in the main elements of the systems with respect to the tasks of solar air conditioning systems (SACS). It is shown that, for practically any sufficiently heavy parameters of external air, solving problems of ensuring its comfortable air parameters can be performed without using traditional refrigeration equipment. The developed SACS solar systems are distinguished by low energy consumption and environmental cleanliness.
\end{abstract}

Keywords: multifunctional systems, absorption system, solar energy, solar collector, absorbent regeneration, evaporative cooling, polymeric materials, comfortable air parameters

\section{References}

1. Doroshenko A.V., Glauberman M.A. (2012) Alternative energy. Refrigerating and Heating Systems, Odessa.

2. Doroshenko A., Silich S. (2010) Heat-cooling multifunction solar systems. Problemele energeticii regionale, , no. 3(14), pp. 44-52. (In Russian)

3. Chen G.M., Zheng J., Doroshenko A., Shestopalov K. (2014) Design and modeling of a collectorregenerator for solar liquid desiccant cooling system. International Sorption Heat Pump Conference, Washington.

4. Doroshenko A., Shestopalov K., Khliyeva O. (2014) Development of new schematic solutions and heat and mass transfer equipment for alternative solar liquid desiccant cooling systems. "International Sorption Heat Pump Conference", Washington.

5. Chen G.M., Doroshenko A.V., Shestopalov K.O., Khliyeva O.Y. (2014) Evaporative coolers of water and air for cooling systems. Analysis and perspectives, Hangzhou, August 31-September 2, 2014 [11th IIR Gustav Lorentzen Conference on Natural Refrigerants, 2014].

6. Chen G.M., Doroshenko A.V., Koltun P., Shestopalov K.O. (2015) Comparative field experimental investigations of different flat plate solar collectors. Solar Energy, no. 115, pp. 577-588.

7. Chen G.M., Shestopalov K.O., Doroshenko A.V., Koltun P. (2015) Polymeric materials for solar energy utilization: a comparative experimental study and environmental aspects. Polymer-Plastics Technology and Engineering.

8. Doroshenko A.V., Antonova A.R., Lyudnitskiy K.V. (2015) Solnechnyie mnogostupenchatyie absorbtsionnyie holodilnyie sistemyi na osnove teplomasoobmennyih apparatov plenochnogo tipa. Refrigeration engineering and technology, 51(2), 25-31.

9. Antonova, A. R. Teoretichne ta eksperimentalne doslIdzhennya protsesIv u gazorIdinnih sonyachnih kolek-torah-regeneratorah alternativnih holodilnih sistem: dis. kand. tehn. nauk : 05.14.06. Odesa, 2014, $205 \mathrm{p}$.

10.Doroshenko A.V., Antonova A.R. Glauberman M.A. (2011) Izuchenie techeniya tonkogo sloya vyazkoy zhidkosti po naklonnoy poverhnosti v kanale s gazovyim potokom. Fizika aerodispersionnyikh sistem, 48, 25-34.

11.Antonova A.R., Kirillov V.H. (2013) Teoreticheskoe ekspe-rimentalnoe izuchenie plenochnyih techeniy $\mathrm{v}$ teploma-ssobmennyih apparatah (isparitelnyih ohladitelyah, gazo-zhidkostnyih solnechnyih kolektorah-regeneratorah) energeticheskih sistem. Refrigeration engineering and technology, 2(142), 20-28 12.Doroshenko A.V., Antonova A.R., Garh Saed. (2015) Multifunctional Solar Systems based on twostage absorbent solution Regeneration. Problemele energeticii regionale, Moldova, Academia de Stiinte, Institutul de Energetica, 1 (27), 44-52. (In Russian) 